\title{
開業歯科医院におけるX線取扱いの実態調査
}

\author{
福岡歯科大学歯科放射線学講座（主任：森 進一郎教授） \\ 小川和久・加治俊夫・森進一郎 \\ 原田吉通・和田忠子
}

昭和56年 1 月 23 日受付

本論文の要旨は第40回（1980年）九州歯科学会総会，および第21回（1980年）日本歯科放射線学会総会に て発表した.

\section{Research on the Actual Conditions of the Radiation Protection in Dental Offices}

\author{
Kazuhisa Ogawa, Toshio Kaji, Shin-ichiro Mori, \\ Yoshiyuki Harada and Tadako Wada \\ Department of Dental Radiology (Chief : Prof. Shin-ichiro Mori) \\ Fukuoka Dental College, Fukuoka, Japan
}

Actual conditions of the radiation protection in 20 dental offices were investigated from December 1979 to March 1980.

The findings of this investigation are reported hereunder:

1. Shielding rooms used exclusively for X-ray examination were found in 7 dental offices only. A simple protective barrier or no protection devices are seen in the rest.

2. Exposure dose measured during production of a maxillar molar radiograph varied from $200 \mathrm{mR}$ to $1000 \mathrm{mR}$ or more according to the judgement of the individual practitioners.

3. However, most of the types of the cones and timers of the dental X-ray machines were found to be in compliance with paragraphs 113 and 115 of ICRP publication 16. The exposure field size of these machines were mostly less than $60 \mathrm{~mm}$ in diameter at the end of the cone. Generally, most of the equipment meet the requirements of the ICRP publications.

4. Also from the observation of other matters for investigations, it was noted that the radiation protection in the general dental offices is rather insufficient or unattended to due to economical reason and other difficulties peculiar to the dental treatment. 


\section{緒}

言

来科渗燎におけるX線撮影の頻度はここ10数年の間に 急激な增加をみせており1，2，またこの数年間でのバ，

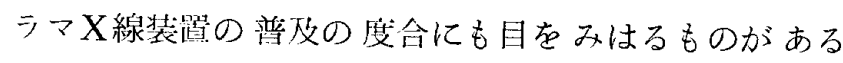
3).

放射線の防護に関してはI C R P (国際湤射線防護委

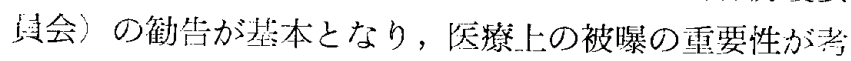
虑され，術者ならびに患者の放射線防護について法律上: の規制がなされているのは凮知の通りで，歯科X楾の

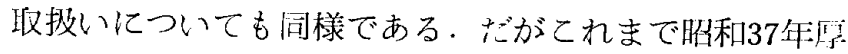
牛省通達により「霆科エックス線装置による撮影のみを 行うにつき，一週間につき 2000 ミリアンメア秒以下で 操作する場所であって，エックス線管及文ひ被照射体から 1.5メートル離れて操作するときは必裂な防謢物在設け る必要がない」とされてきた。著者ら $(1978)^{4}$ の顺和 51年に行なった福岡・山口雨県の霆科医院に刘するアン

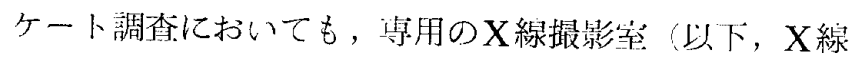
㝒とする。で撮影を行なっているのは数\%にすぎなか った。

その後, 蒾科 $X$ 線撮影の頻渂の增加あるいは心ハラマ

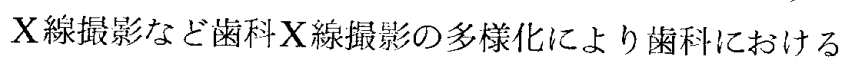
X線被曝の問題が兒逃せないものとなり，胎和53年 7 月 には咸生省より「バノマ・エックス線装置の埸合はも よより,デンタル・エックス線装菅の場合であっても，

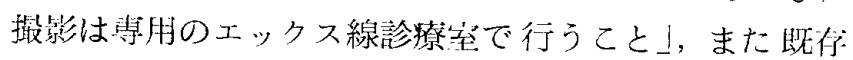
の施設におけるデンタルX線装箇のみの使用については 当面の間は衙立等の遮蔽物を游いること，またこの場命 でも何らかの機会をとらえてすみやがX線鈭を整備す るようにとの通達が出されるに至っている。

まずはこのような背景の中で, 雨科におけるX線双扱

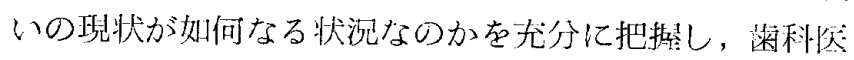

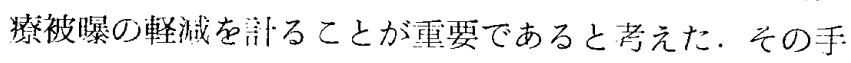
始めとして，而る地区に扔ける一般開業㐘科矢院20㺴䧊

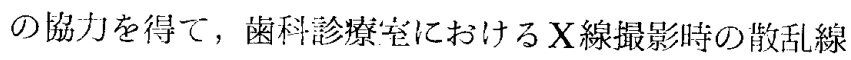
の測定を中心とし，その他いくつかの項目についての奉 態調相を行なった，その綃兴について検討したので報! する。

\section{調 查 方 法}

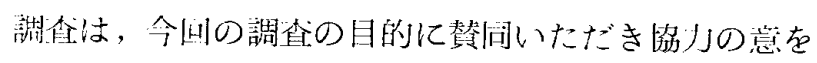

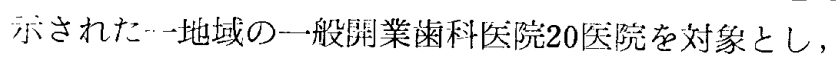
昭和 54 年: 12 月より环和 55 年 3 月にかけて行なった。

まず多洲調盛として実地に，X線装袈の種類, 台数,

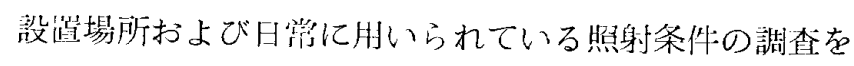
行なった後, デンタルX線装筫については照射野の大き さならびに照射線量の测定を行なった，照射野の大きさ は照射简先端の位置および 照射筒先端より $10 \mathrm{~cm}$ 前庘の 隹置にブレバックフィルム (Kodak X-OMAT TL film〉存誼き，それぞれ照射，現像後，その照射野の

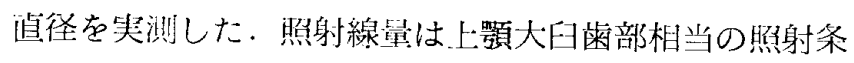

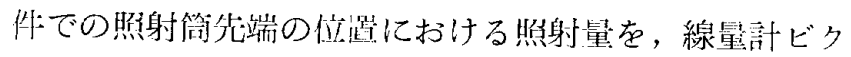
トリン $470 \mathrm{~A}$ 党用いて测定した。

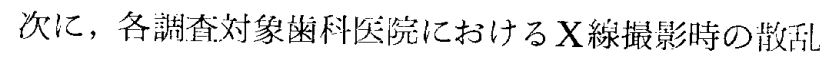
線の測定を行なった・デンタルX線撮影時とバノラマX 線撮影時とのそれでれについて，散乱体としてファント

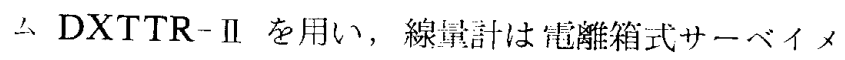
ーターAloka ICS-151 およびビクトリン $470 \mathrm{~A}$ 朋い

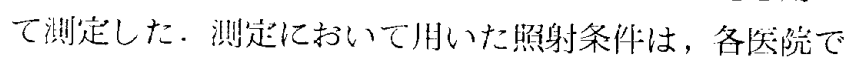
日常用いられている条件である. 各测定点は, 常識的に

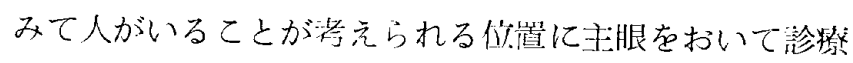
宅内外に設定した。

同時に，次の事項についてアンケート法による調查を 行なった。

1) 竛燎又夕ッフ

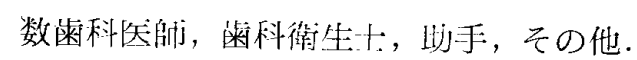

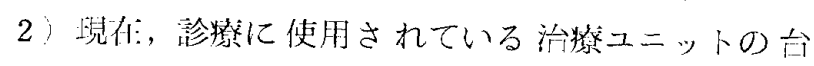
数.

3) 1 月中1聯和155年 の撮影枚数 デンタル, 八ノラマ, その他.

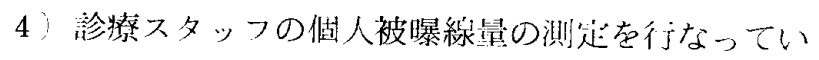
るか、今後, 行なう計岫はあるか。

5) 晸乱線，漏㦼線の测定を行なっているか.

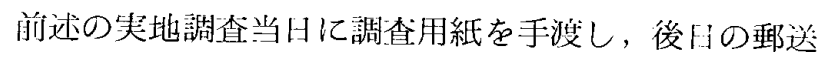
による间答をお願いした。11医院からの问答が得られ た。

\section{調 查 結 果}

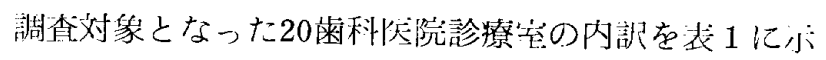
した。バラマX線装䈯のみがX線至に設谓されていた のが 4 医院, バノラマX線装置とデンタルX線装渞とが

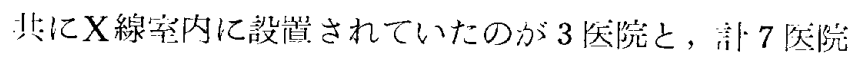

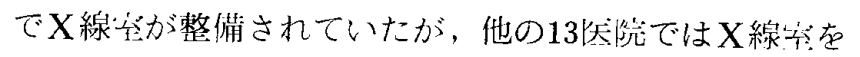
衏していなかった。

デンタルX線装温およでバラマ $\mathrm{X}$ 線装㯰の設真場所

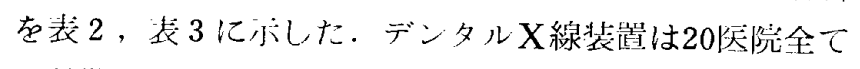

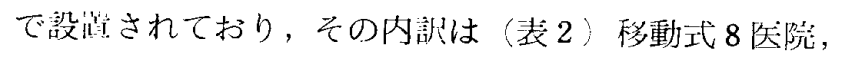

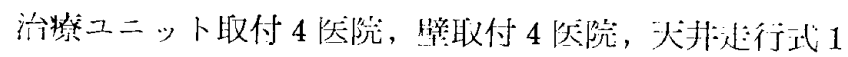


表 1 調査対象㐘科医院の内訳

A. 建造別

\begin{tabular}{c|c|c}
\hline \hline $\begin{array}{c}\text { コンク } \\
\text { 木 }\end{array}$ & & 7 \\
\hline & & 13 \\
\hline & & 20 \\
\hline
\end{tabular}

\section{B . X線室の有無}

\begin{tabular}{cc|c}
\hline \hline パノラマ・デンタル共用 & 3 \\
パノラマのみ有 & 4 \\
無 & し & 13 \\
\hline \multicolumn{2}{c|}{} & 20 \\
\hline
\end{tabular}

表 2 デンタルX楾装置の設置状況

\begin{tabular}{|c|c|c|c|c|c|c|c|}
\hline $\bar{j}$ & V & タル X & 線 告 & 賏 & 医 & 院 & 数 \\
\hline 移 & & 動 & 式 & & & 8 & \\
\hline \multirow[t]{2}{*}{ ב } & $=$ & ッ ト 取 & 付 & 1台 & & 2 & \\
\hline & & & & 2 台 & & 2 & \\
\hline \multirow[t]{3}{*}{ 壁 } & & 取 & 付 & 1 台 & & 2 & \\
\hline & & & & 2 台 & & 1 & \\
\hline & & & & 3 台 & & 1 & \\
\hline 天 & 井 & 走 行 & 式 & & & 1 & \\
\hline $\mathrm{X}$ & 線 & 宝内 設 & 狊 & & & 3 & \\
\hline \multicolumn{5}{|c|}{ 計 } & & 20 & \\
\hline
\end{tabular}

表 3 パノラマX線装犆の設置状沉

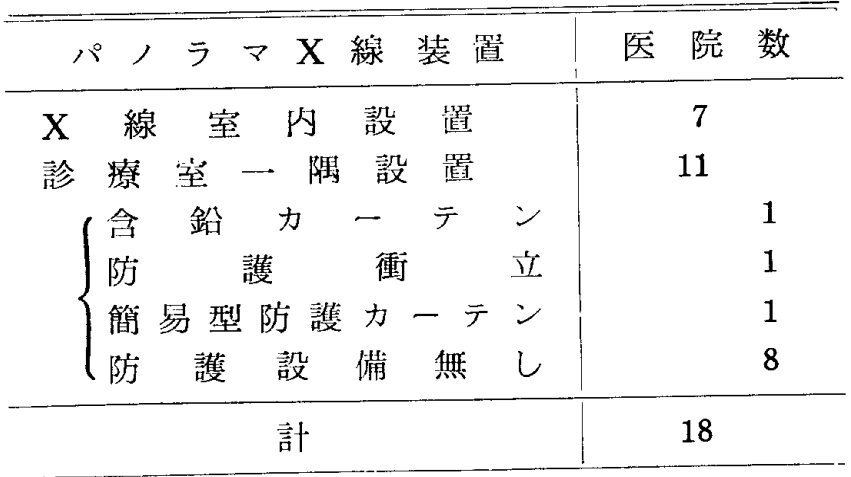

祭院で，これらがいわゆる診療室内に設置されていた医 院であり，残り 3 医院が曹用のX線室内に設置されてい た医院である。

パノラマX線装置は調査対象 20 医院のうち 18 医院で設 置されておうり，その内訳は（表3）X線室内に設置され ているのが 7 矤院で, 他の11医院では診燎室の一隅に設 误されていた。そのうち，鉛衝立等を用いての防護がな
されているのが 3 医院，何の防謢もなされていないのが 8 医院であった。

各歯科医院のデンタルX線装㯰（2台以上を有する医 院については主として使用されている装置）の照射筒お よびタイマーの型式別の分類結果を表 4 亿示した。照射 筒については砲弾型 7 台, 開放端型13台であり, タイマ 一型式についてはゼンマイ式 4 台, 電子管式16台であっ た。

表 4 デンタルX線装置の照射筒ならびにタイマー の型式

\begin{tabular}{|c|c|c|c|}
\hline 照射筒】タイマー & ゼンマイ式 & 電子管式 & 計 \\
\hline 弾 型 & 3 & 4 & 7 \\
\hline 開 放 端 型 & 1 & 12 & 13 \\
\hline 計 & 4 & 16 & 20 \\
\hline
\end{tabular}

これらのデンタルX線装置の照射野直径の実測值を表 5 亿示した。照射筒先端の位置で（表 5-A）最小值を 示したもの $47 \mathrm{~mm}$, 最大值を示したもの $78 \mathrm{~mm}$ であり, 直徍 $60 \mathrm{~mm}$ を超えるものが 6 台であった．照射筒先端よ り $10 \mathrm{~cm}$ 前方の位置では（表 $5-B$ ）最小值を示したも の $81 \mathrm{~mm}$, 最大值を示したもの $125 \mathrm{~mm}$ であった。

表 5 デンタルX線装置の照射野の大きさ

A. 照射筒先端位犆

\begin{tabular}{|c|c|c|c|c|}
\hline 照 & 射 野 直 & 圣 (mm) & 医 & 院 数 \\
\hline & 40 & 49 & & 1 \\
\hline & $\sim$ & 59 & & 13 \\
\hline & $\sim$ & 69 & & 4 \\
\hline & 70 以上 & & & 2 \\
\hline \multicolumn{3}{|c|}{ 計 } & & 20 \\
\hline
\end{tabular}

B . 照射筒先端より $10 \mathrm{~cm}$ 位置

\begin{tabular}{c|c|c}
\hline \hline 照射野直 径 $(\mathrm{mm})$ & 医 院 数 \\
\hline 70 & $\sim 79$ & 0 \\
80 & $\sim$ & 11 \\
90 & $\sim$ & 69 \\
100 & $\sim 109$ & 6 \\
110 & $\sim 119$ & 1 \\
120 以上 & 1 \\
\hline
\end{tabular}


デンタルX線撮影の中で最大の照射時閂ならびに照射 線量在必要とする上類大曰菌部を撮影した場合を基準と して, 各医院で通常に用いられている照射時間ならびに その照射時間に対灾した，X線装置の照射筒先端位置に おける照射線量を調查測定した紹果を表 6 ，表 7 亿示し た.照射時間（表 6 ）をみると0.6秒から3.0秒以上まで 分布し，0.9秒以下 3 医院，1.0 1.9秒 12医院，2.0 2.9 秒 3 医院，3.0秒以上 2 医院であった。乙れに対応し

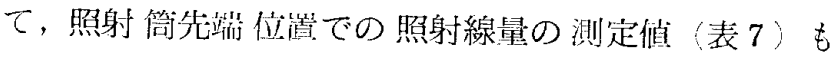
$250 \mathrm{mR}$ から $1000 \mathrm{mR}$ 以上までの㕕い範国に分倠してい た。

表 6 デンタルX線撮影(上䫑大曰蒾部、における㫮 射時閻

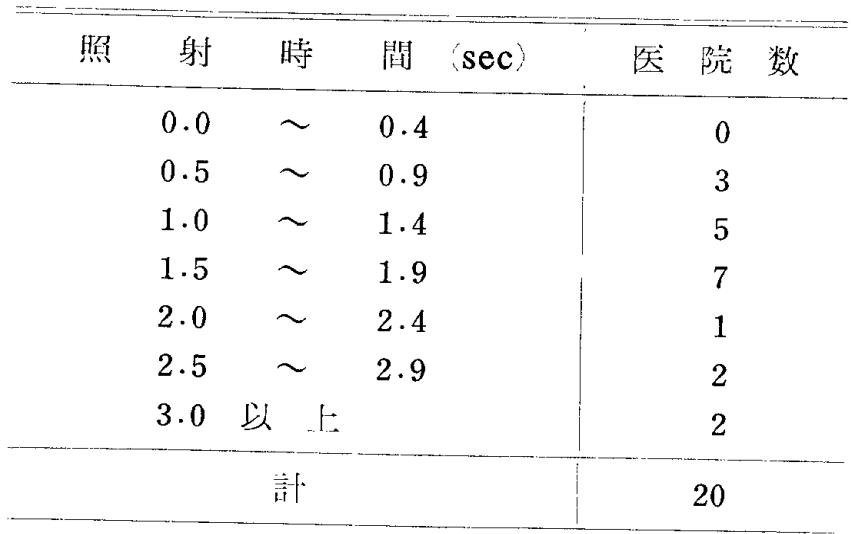

装 7 デンタルX線撮影(上䫑大曰蒾部) における照 射線量:

\begin{tabular}{|c|c|c|c|c|c|c|}
\hline 照 & 射 & 線 & 量 (mR) & 医 & 院 & 数 \\
\hline & 200 & $\sim$ & 299 & & 2 & \\
\hline & 300 & $\sim$ & 399 & & 2 & \\
\hline & 400 & $\sim$ & 499 & & 4 & \\
\hline & 500 & $\sim$ & 599 & & 3 & \\
\hline & 600 & $\sim$ & 699 & & 1 & \\
\hline & 700 & $\sim$ & 799 & & 4 & \\
\hline & 800 & $\sim$ & 899 & & 2 & \\
\hline & 900 & $\sim$ & 999 & & 1 & \\
\hline & 1000 & \multicolumn{2}{|c|}{ 以上. } & & 1 & \\
\hline & & \multicolumn{2}{|l|}{ 計 } & & 20 & \\
\hline
\end{tabular}

次に，アンケート調査の結果を表 8 , 表 9 , 表10亿热

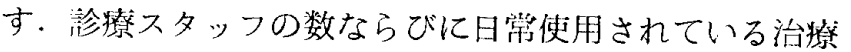
ユニットの台数についての回答（表 8 ）をみると，1人 の蒾科医師が 2 台の治燎二ニットを使って掺燎を行なっ ている院院がはとんどであった。

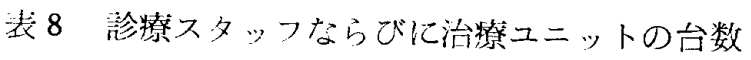

A. 㐘科殹師们人数

\begin{tabular}{rl|r|r}
\hline 人 & & 数 & 回 答 数 \\
\hline 1 & 人 & & 11 \\
2 & 人 以 & 0 \\
\hline
\end{tabular}

B. 眯科衛生士, 助手, その他の人数

\begin{tabular}{|c|c|c|c|c|c|c|}
\hline 人 & & & & 数 & |ii] & 答 数 \\
\hline & 1 & $\sim$ & 2 & 人 & & 8 \\
\hline & 3 & $\sim$ & 4 & 人 & & 2 \\
\hline & 5 & $\sim$ & 6 & 人 & & 1 \\
\hline
\end{tabular}

C. 治爒ユニットの台数

\begin{tabular}{cl|c|c}
\hline 台 & & 数 & 回 答 数 \\
\hline 1 & 台 & 0 \\
2 & 台 & 9 \\
3 & 台 & 2 \\
\end{tabular}

表 91 力月間 哟和55华 1 月 の撮影枚数

A・デンタルX線撮影

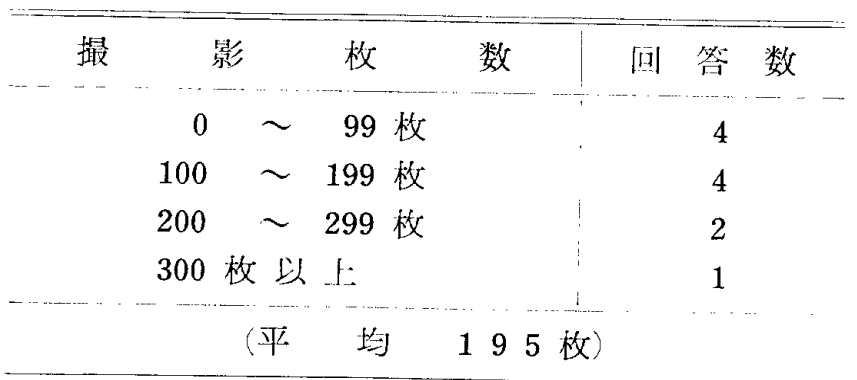

B・ハノラマX線撮影

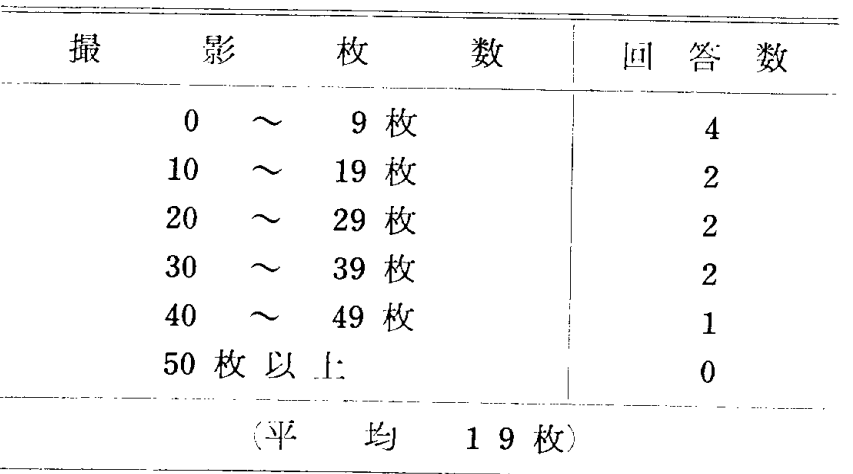

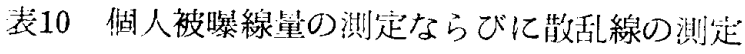

测定項目しているしていないしたこよがある

個人被殡線崖: 0011

散 活 線 1001 
各菊科医院での 1 力月当りのX線撮影枚数を炤和 55 年 1 月分について調查した結果, デンタルX線撮影（表 9 －A）については最高876枚，最低13枚で，平均195枚の 撮影が行なわれていた。・バラマХ線撮影（表 9-B） については最高49枚, 最低 4 枚で, 平均19枚の撮影が行 なわれていた，その他の口外法撮影はいずれの医院にお いても行なわれていなかった。

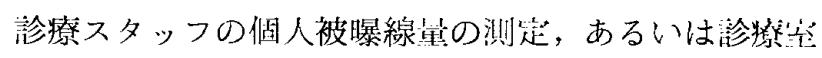
内などにおける北乱線や漏浅線の测定を行なっているか という設問に対しての回答は表10の通りであった。個人 被曝線量の測定を行なっている䀢院は無かった。このて とについて今後行なう予是があるかという設問に対し て，あると回答したものが 4 满院，ないといら回答が 4 医院，未記入 3 医院であった。敀乱線，漏洩線について は，1垁院で過去に一度，開業時（昭和54年）に測定し たことがあるという四答が得られたが，他の医院では行 なったととがないという回答であった。

以上の調查絬果をふまえ, 各雬科医院で通常に行なわ れているX線撮影時の散乱線を测定した絬果表表11〜裴
14に示した。

表11はパノラマX線撮影時の場合で, 一回の撮影に際

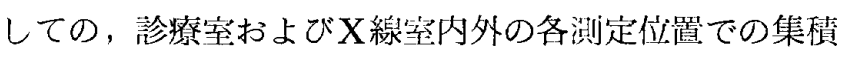
線䭪を $\mu \mathrm{R}$ の単位で示した。パノラマX線装崖を有する 18医院は次のように，大きく3つの群に分類することが できる。すなわち，I群は専用のX線室をもつ7医院， II 群はX線空は無いが何らかの防護設俩がある 3 医院，

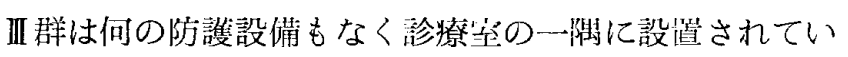
る 8 医院である。

I. 群（表11）のNo. 1〜 5 の医院ではX線室の外での散 乱線は测定されなかった。№.6，№.7の医院ではX線空 外への散乱線の洩れが測定された。II群，III群（表11） の各医院について，それぞれの医院における䓂療空つ ロアーの広さ，X線装置の配㯰および撮影条件の違いか ら個々の雨科医院の状況に心じた测定結果をみた。

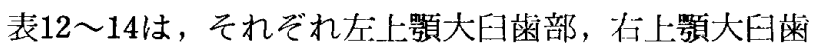
部, 上枵真前捆部におけるデンタルX線撮影を行なった時 の散乱線の測定結果を示している。デンタルX線撮影は X線䇪のない医院においては注燃ユニットの上で行なわ

表11 パノラマX線撮影時の敞乱線

\begin{tabular}{|c|c|c|c|c|c|c|c|c|}
\hline \multirow{2}{*}{ 群 } & & 科 & \multicolumn{3}{|c|}{ 测 } & 定 & 值 & $(\mu \mathbf{R})$ \\
\hline & 知 & 院 & 制御 盤 & $\begin{array}{l}\text { 箖 } \\
\text { ユニット }\end{array}$ & 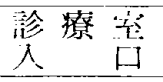 & 浸 付 & 待合等 & 㘹 \\
\hline \multirow[t]{7}{*}{ I } & No. & 1 & 0 & 0 & & & & 0 (X線堂壁の外 \\
\hline & & 2 & 0 & 0 & & & & 0 (X線室䜃の外) \\
\hline & & 3 & 0 & 0 & & & & 0 (X線室壁の外) \\
\hline & & 4 & 0 & 0 & & & & 0 (X線室壁の外) \\
\hline & & 5 & 0 & 0 & & & & $0(X$ 線等壁の外 \\
\hline & & 6 & 0 & 15 & & & & 40 (X線垶壁の外) \\
\hline & & 7 & 20 & & & & & 50 (X線空壁の外) \\
\hline \multirow[t]{3}{*}{ II } & & 8 & 20 & 20 & & & & $\begin{array}{l}60 \text { (技工琴) } \\
50 \text { (防護力ーテンの後) }\end{array}$ \\
\hline & & 9 & 300 & 50 & 50 & 0 & 0 & 90 (防護衝立の後) \\
\hline & & 10 & 100 & 10 & & 0 & 0 & $\begin{array}{l}20 \text { (据闇 } \\
100 \text { (防護カーテンの後) }\end{array}$ \\
\hline \multirow{8}{*}{\multicolumn{2}{|c|}{ III }} & 11 & 50 & 0 & & 0 & 0 & 80 (技工“公 \\
\hline & & 12 & 10 & 0 & & 10 & 0 & 20 通 路〉 \\
\hline & & 13 & 340 & 0 & 10 & 0 & & 120 居 閒 \\
\hline & & 14 & 60 & 60 & & & & \\
\hline & & 15 & 80 & 200 & 20 & 10 & 5 & 50 技上管) \\
\hline & & 16 & 310 & 260 & 20 & 30 & 0 & 30 技工它 \\
\hline & & 17 & 70 & 170 & 10 & 70 & 10 & \\
\hline & & 18 & 300 & 110 & 30 & 10 & 30 & \\
\hline
\end{tabular}

I群：X線富有り

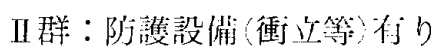

III 咩：防護設備(衝嘼等)無し 
れているので, 調查対象20医院をパノラマX線摄影の場 合（表11）とは違って, 彰獠突内での治療ユニットの配 䈯のしかたによって3つの群に分類した（図 1 )。I群 は専用のX線室を有する 3 知院，II群は搒裺室フロアー が各治䝤ユニット毎に独立したコンボーネント型の 3 㗨 院，III群はひとつのフロアーに隔壁なしに数台の治燎ב ニットが前べられている14矢院である。測定值は線量率 $\mathrm{mR} / \mathrm{h}$ の単位で示した.

\section{考察}

今间の調查に対する協力䨑科医院群においては，1人 の歯科医師が 2，3台の治燎ユニット在父而に用いて讋 裺している䧜院が大半であった。このてとは著者らが経 験的に考えて，一般的な鬥業茵科医院の規模であろう之 思われる. 1 力月間でのX線贞真の撮影枚数については

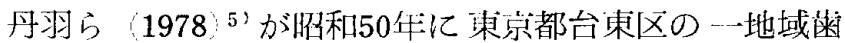

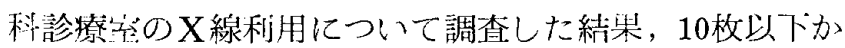
ら400枚まで分布するが100枚前後が最も多かったと迟べ ている。またバラマX線撮影については高小ら 1979 6) が昭和52年に埼玉県下の柬科医院について同様の調査 を行ない， 1 山平地 5 枚以内の撮影が大半であったと还 べている．今可の調查刘象医院群についても同様の結果 であった。この程度が開業荿科医院における一般的な掫 影枚数であろうと思われる。

デンタルX線装置の照射㣞とタイマーの哲式について は1971年 I C R P 勧行 ${ }^{77}$ は，歯科用X線装置の照射简は 版乱線の多い砲弹型コーンよりも照射野を限走した開放 端型コーンに，また照射夕イマーは䢀現性が高くて，過 剩な偶発的照射がない電子管式のタイマーにする上うに としている，藷者ら”加昭和51年に䘕なった福岡・山日 耑県の歯科快院のX線取扱いに関する調查では怕式のゼ ンマイ式タイマーが57\%，また照射信についても砲弹型 のものが54\%を方めていた。これれ比べて令回の調査で

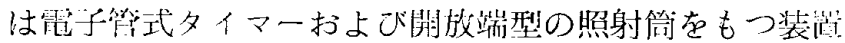

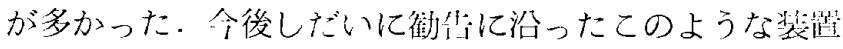
に代筸えされていくものと思われる。

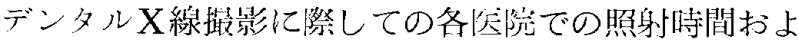
びそれに対忘する照射線量についての調查結果では，か なり広い範囲でのばらつきが見られた。これは各猋院に おける撮影趾倠の違い，使用フィルムの感度の違い，現 像処理方法の違いなどによるものであろうと若えられ

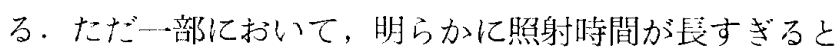
思われる㗨院が $2 ， 3$ 罗うけられた。乙れらの掭院につ いては, 淍查終了後, われわれより照射時開知維の提心
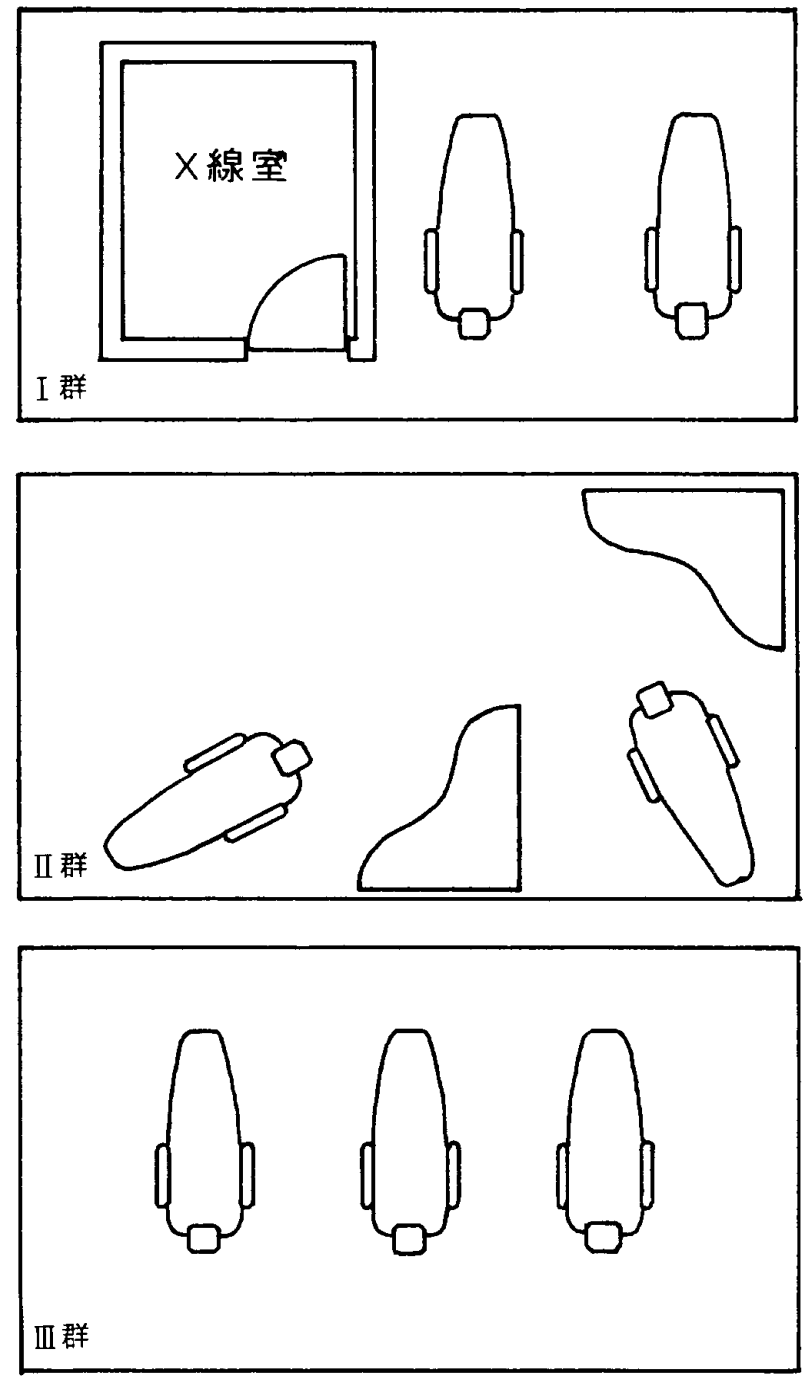

I 群：独立したX線室をもつもの

II 群 : コンポーネント型の診療室

III群：|フロアー型の診療室

脳 1 デンタルX線撮影 表12〜14時におけるI〜 III群の分類

がなされ，その後の掓影では收善されている.

X線室の整俑状沅をみてみると，バラマX線装觜に かいてはこれを有する18㗨院のうちち 7 医院で，デンタ

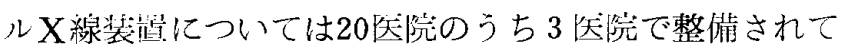
いた。

バラマX線装岨については, 祭䝤法施行規則第 30 条

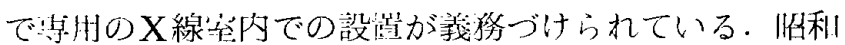
53年のX線公在設けるようにとの意の性省通達以来，

X線至在設蹎する医院の数は罣えてきているように見涭 けられる，今回の调查対象医院のうちでも鼠近に新築あ るいは收築がなされた医院では，そのほとんどの智院で

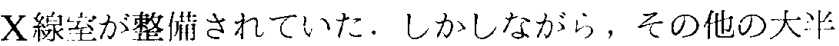


表12 デンタルX線撮影(左上顎大日膰部)時の散乱線

\begin{tabular}{|c|c|c|c|c|c|c|c|c|c|c|c|}
\hline \multirow{2}{*}{$\mathrm{H}^{\mathrm{O}}$} & \multirow{2}{*}{\multicolumn{2}{|c|}{$\begin{array}{l}\text { 莱 科 } \\
\text { 医 院 }\end{array}$}} & \multirow{2}{*}{$\begin{array}{c}\text { 照 身 } \\
\text { 时 間 } \\
\text { (sec) }\end{array}$} & & \multicolumn{2}{|r|}{ 測 } & 定 & \multicolumn{2}{|c|}{ 值 $(\mathrm{mR} / \mathrm{h})$} & \multirow[b]{2}{*}{$\begin{array}{l}\text { タイマー } \\
\text { ホタタ }\end{array}$} & \multirow[b]{2}{*}{$\begin{array}{l}\mathrm{X} \text { 線窒 } \\
\text { 壁の补 }\end{array}$} \\
\hline & & & & $\begin{array}{l}\text { 隣 } \\
\text { ユ }=\text { 掞 }\end{array}$ & 受 付 & $\begin{array}{l}\text { 診療公 } \\
\text { 人 }\end{array}$ & 待合窒 & $\begin{array}{l}\text { ユニット } \\
\text { 足 も }\end{array}$ & $\begin{array}{l}\text { 各ユニッ } \\
\text { 卜間 }\end{array}$ & & \\
\hline \multirow[t]{3}{*}{ I } & No. & 1 & 1.8 & & & & & & & 0 & 0 \\
\hline & & 2 & 1.0 & & & & & & & 20 & 0 \\
\hline & & 3 & 1.5 & 4 & 6 & 4 & 0 & & & 8 & 76 \\
\hline \multirow[t]{3}{*}{ II } & & 4 & & 4 & 0 & 4 & 0 & 84 & & & \\
\hline & & 5 & & 0 & 0 & 2 & 0 & 28 & & & \\
\hline & & 6 & 0.8 & 3 & 3 & 0 & 0 & & & 14 & \\
\hline \multirow[t]{14}{*}{ III } & & 7 & 0.6 & 60 & 4 & 4 & 0 & 56 & & & \\
\hline & & 8 & 0.7 & 14 & 2 & 4 & 2 & 12 & 68 & & \\
\hline & & 9 & 1.0 & 10 & 0 & 4 & 2 & 14 & 14 & & \\
\hline & & 10 & 1.2 & 30 & 48 & 4 & 0 & 40 & 70 & & \\
\hline & & 11 & 1.2 & 32 & 2 & 2 & 2 & & $>100$ & & \\
\hline & & 12 & 1.4 & 8 & 8 & 6 & 4 & 50 & 26 & & \\
\hline & & 13 & 1.5 & 12 & 0 & 2 & 0 & 20 & 36 & & \\
\hline & & 14 & 1.5 & 20 & 34 & 10 & 100 & 38 & 40 & & \\
\hline & & 15 & 1.5 & 20 & 2 & 4 & 0 & 60 & 100 & & \\
\hline & & 16 & 1.5 & $>100$ & 6 & 10 & 4 & $>100$ & 70 & & \\
\hline & & 17 & 1.5 & 2 & 4 & 4 & & 34 & 90 & & \\
\hline & & 18 & 2.5 & 12 & 0 & 0 & 0 & 14 & 34 & & \\
\hline & & 19 & 2.5 & 8 & 2 & 2 & 0 & 10 & 34 & & \\
\hline & & 20 & 3.0 & 20 & 6 & 6 & 2 & 40 & 24 & & \\
\hline
\end{tabular}

I群：X線烓付り

I幦：コンホーネント型

III群：1フロア型

の炈院ではX線至の必要性は諗めながらも，経済的な理 由あるいは廷造物收築の困難性から，X線宅の設置がな されないままに放圆されているようである。

デンタルX線装置については，乙れまで移動式のX線 装翼であるという解秎から，ある条件の下での使用につ いてはX線害を設けなくてもよいとされてきた。しかし 㕷和53年原生省通達によりデンタルX線装䈯についても X線䒧が必要となったが，乙れまで用いられてきた装䈯 については暫定的に衝立等の遮㫌物を設けた上で使用し

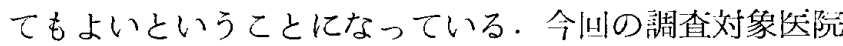

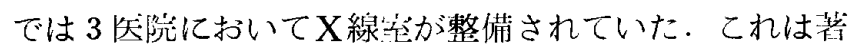

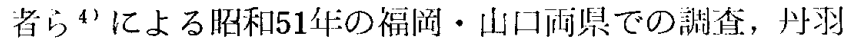

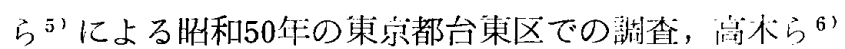

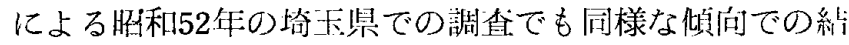
果が得られている.デンタルX線撮影についてX線至を 独立させた場合，歯科讋䝤に打ける特有的治䅫法のため

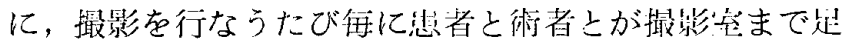
を連ばなければならないことの煩わしさが，X線記設
の大きな障害となっているようである，特に，根管治潦 での抜骵時あるいは根光時における撮影においては，思 者をX線奔まで移動させることの困難性あるいは時間的 なロスの問題から，治療ユニットの上でそのままX線撮 影が行なわれているのが現状のようである。しかしX線 のもつ有㫪性については周知の事実である以上，X線の 防護を意たることは問題がある.しかしながらさらに， 独立したX線望で撮影を行なうことのむずかしさもまた 事実としてとらえ，経淙的，空閻的なものを考慮しなが ら，何らかの抾により早殸に解沋する必要がある。だ が垷時点において，治轑ユニット上でX線撮影を行なわ ざるをえない場合でも，せめて鎑衝立等の遮蔽物で当該 ユニットを明む等の防謢が行なわれるべきであろう。

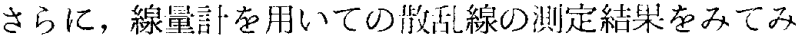
ると，せっかくX線定が整倩されている䀢院でも，わず かではあるが，一部でX線至からの漏浅が測定された例 があった。パノラマ X線撮晾の場合（表11），№.6 䀢院 に扔いてX線空の壁から約 $1 \mathrm{~m}$ 離机た治療ュニットの位 


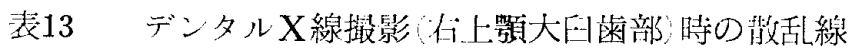

\begin{tabular}{|c|c|c|c|c|c|c|c|c|c|c|c|}
\hline \multirow{2}{*}{ 群 } & \multirow{2}{*}{$\begin{array}{l}\text { 凅 } \\
\text { 快 }\end{array}$} & \multirow{2}{*}{$\begin{array}{l}\text { 科 } \\
\text { 院 } \\
\end{array}$} & \multirow{2}{*}{$\begin{array}{c}\text { 照 射 } \\
\text { 照 } \\
\text { (sec }\end{array}$} & \multicolumn{3}{|r|}{ 测 } & 定 & \multicolumn{2}{|r|}{$(\mathrm{mR} / \mathrm{h}$} & \multirow[b]{2}{*}{$\begin{array}{l}\text { タイマー } \\
\text { ボタン }\end{array}$} & \multirow[b]{2}{*}{ 壁 線羑 } \\
\hline & & & & $\begin{array}{l}\text { 隣 揪 } \\
\text { ユニット }\end{array}$ & 受 付 & 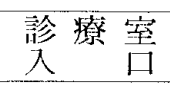 & 待合等 & 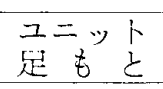 & $\begin{array}{l}\text { 条ユニッ } \\
\text { 卜間 }\end{array}$ & & \\
\hline \multirow[t]{3}{*}{ I } & No. & 1 & 1.8 & & & & & & & 0 & 0 \\
\hline & & 2 & 1.0 & & & & & & & 26 & 0 \\
\hline & & 3 & 1.5 & 2 & 4 & 0 & 0 & & & 14 & 36 \\
\hline \multirow[t]{3}{*}{ II } & & 4 & & 4 & 0 & 0 & & $>100$ & & & \\
\hline & & 5 & & 2 & 0 & 0 & 0 & 30 & & 2 & \\
\hline & & 6 & 0.8 & 2 & 4 & 0 & 0 & & & 4 & \\
\hline \multirow[t]{14}{*}{ III } & & 7 & 0.6 & 100 & 8 & 24 & 0 & 76 & & & \\
\hline & & 8 & 0.7 & 8 & 0 & 4 & 0 & 18 & 28 & & \\
\hline & & 9 & 1.0 & 12 & 0 & 4 & 2 & 20 & & & \\
\hline & & 10 & 1.2 & & & & & & & & \\
\hline & & 11 & 1.2 & 16 & 8 & 10 & 4 & 24 & 100 & & \\
\hline & & 12 & 1.4 & 4 & 4 & 4 & 2 & 30 & 24 & & \\
\hline & & 13 & 1.5 & 10 & 0 & 4 & 0 & 20 & 50 & & \\
\hline & & 14 & 1.5 & 34 & 36 & 32 & 6 & & 84 & & \\
\hline & & 15 & 1.5 & 22 & 2 & 10 & 0 & 46 & $>100$ & & \\
\hline & & 16 & 1.5 & 60 & 10 & 12 & & $>100$ & & & \\
\hline & & 17 & 1.5 & & 6 & 6 & 4 & 26 & 100 & & \\
\hline & & 17 & 2.5 & 8 & 10 & 4 & 2 & 10 & 20 & & \\
\hline & & 19 & 2.5 & 12 & 2 & 2 & 0 & 16 & 30 & & \\
\hline & & 20 & 3.0 & 16 & 6 & 6 & 4 & 42 & 44 & & \\
\hline
\end{tabular}

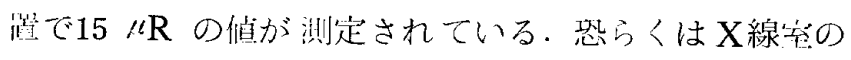

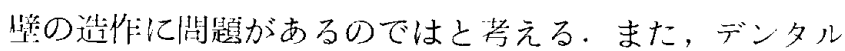
X線撮影時（表12〜14）に扔いては, No.3䀢院のX線定 からの漏波がある例の他に，X線公は設监されているが 惜しむらくはタイマーがX線公内にあり，タイマ一操作 がX線室内で行なわれているために術者の防護には當味 在なさないNo. 2 园院の例があり，タイマー操作㒀监で20 $\mathrm{mR} / \mathrm{h}$ あるいは $26 \mathrm{mR} / \mathrm{h}$ の綮活線が澌定された。しか

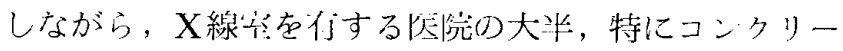

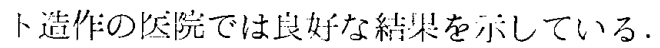

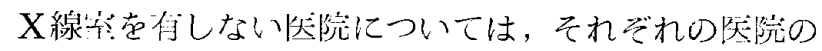

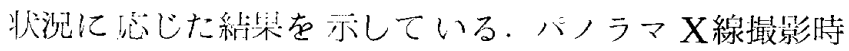
（表11)に予いては，通常に居閻として使用している隣 论で120 几R の值を示したNo.13医陵の例もあった。これ

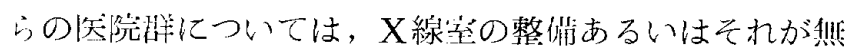
理であれば鈖衝立等による游護が紫まれるところであ る.デンタルX線掫影の場合（表12〜14）においては， II群の各治㹸ユニットが独立唒管になったコンホーネン

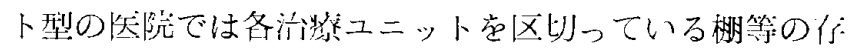

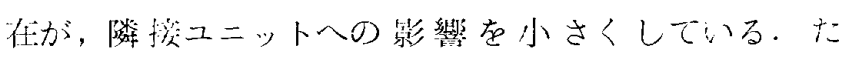
だ, デンタルX線撮影の埸合は, バノラマX線掫影の

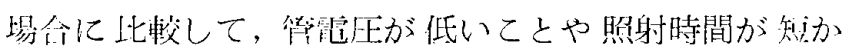
いことのために政乱線は小さいようである。今可の詶 査㳩定で使用した線量計においても，デンタルX線撮影 時の测定の满合には，バラマX線撮影時の測定で用い た集䅡線早（フルスケール：1000 ル $\mathbf{R}$ ) では测定不问能 であったために，やむを得ず線輿渗(フルスケール：

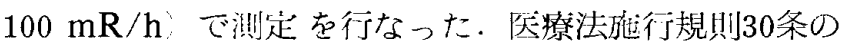
4 によれば， 1 週閶当り 3 時閂未満使用の渗断用X線装

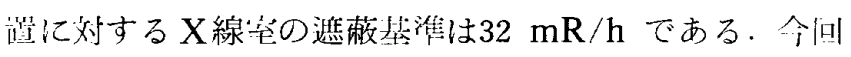

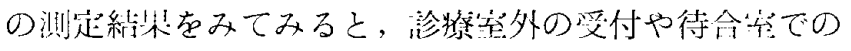
值は，№.10阡院之NNo.14知院との例を除いて，この值より

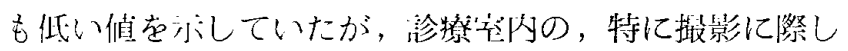
ての当輆ユニットの近傍あるいは隣损ユニットの位谓で は，六れ相纫の非乱線が测定された。

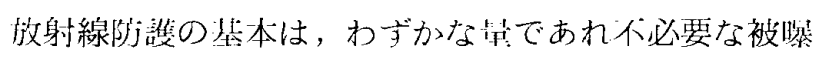
は避けるということにある．ＩＣＲＰ衔!沉扔いても， 河しような考え方が根本になっている。この上うな観点 
表14 デンタルX線撮影(上顎前橉部)㭙の毕乱線

\begin{tabular}{|c|c|c|c|c|c|c|c|c|c|c|}
\hline \multirow{2}{*}{ 群 } & \multirow{2}{*}{$\begin{array}{l}\text { 㐘 科 } \\
\text { 医 院 }\end{array}$} & \multirow{2}{*}{$\begin{array}{c}\text { 䚢 射 } \\
\text { 洔 } \\
\text { (sec) }\end{array}$} & \multicolumn{3}{|c|}{ 测 } & 定 & \multicolumn{2}{|c|}{ 值 $(\mathrm{mR} / \mathrm{h})$} & \multirow[b]{2}{*}{$\begin{array}{l}\text { タイー } \\
\text { ボタン }\end{array}$} & \multirow[b]{2}{*}{$\begin{array}{l}\mathrm{X} \\
\text { 線 窒 } \\
\text { 刿 }\end{array}$} \\
\hline & & & $\begin{array}{l}\text { 隣 } \\
\text { ユニット }\end{array}$ & 受 付 & 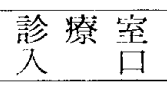 & 待合室 & 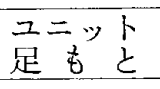 & $\begin{array}{l}\text { 各ュニッ } \\
\text { ト間 }\end{array}$ & & \\
\hline \multirow[t]{3}{*}{$\mathrm{T}$} & No. 1 & 1.0 & & & & & & & 0 & 0 \\
\hline & 2 & 1.0 & & & & & & & 20 & 0 \\
\hline & 3 & 0.8 & 4 & 2 & 0 & 0 & & & 6 & 28 \\
\hline \multirow[t]{3}{*}{ II } & 4 & & 6 & 0 & 0 & 0 & 96 & & & \\
\hline & 5 & & 0 & 0 & 2 & 0 & 24 & & & \\
\hline & 6 & 0.5 & 4 & 4 & 0 & 0 & & & 4 & \\
\hline \multirow[t]{14}{*}{ III } & 7 & 0.6 & 60 & 8 & 6 & 0 & 88 & & & \\
\hline & 8 & 0.4 & 4 & 2 & 2 & 0 & 18 & 30 & & \\
\hline & 9 & 1.0 & 18 & 0 & 4 & 2 & 36 & & & \\
\hline & 10 & & & & & & & & & \\
\hline & 11 & 1.2 & 30 & 2 & 10 & 6 & 24 & 98 & & \\
\hline & 12 & 1.5 & 8 & 4 & 6 & 6 & & 28 & & \\
\hline & 13 & 1.0 & 10 & 0 & 2 & 0 & 24 & 24 & & \\
\hline & 14 & 1.0 & 18 & 26 & 32 & 6 & & 54 & & \\
\hline & 15 & 1.5 & & 2 & 8 & 2 & 90 & $>100$ & & \\
\hline & 16 & 1.5 & 38 & 4 & & 10 & $>100$ & & & \\
\hline & 17 & 1.0 & & 4 & 4 & 4 & 60 & 100 & & \\
\hline & 18 & 2.5 & 8 & 2 & 4 & 2 & 6 & 28 & & \\
\hline & 19 & 2.0 & 6 & 0 & 0 & 0 & 8 & 30 & & \\
\hline & 20 & 3.0 & 20 & 4 & 6 & 2 & 40 & 36 & & \\
\hline
\end{tabular}

からすれば，パノラマX線装㺳はもとより，デンタルX 線装置についても㯖用のX線撮影室を設置するというの が望ましい方向であろう。しかしながら，前にも述べた ように，特にデンタルX線撮影においては，粜科治療法 の特殊性により，蓴用のX線室を独立させることは診療 を困難にするか，あるいは不可能な状況を作り出すこと となり，一般的に良い診療形態はとれないこととなる。 この矛盾について何らかの解決法を早急に筧い出す必要

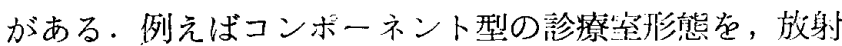
線防謢の実状に忍じたもの一收良していくのも一つのち 法であろう。

文
結

論

一般開業歯科院院におけるX線取扱いの実態について 調査を行なった。

今回の調查から，歯科医院に抢ける放射線防護の垁状 は，まだ充分でない点がいくつかみられた。このことに ついては，各菌科医師の放射線防護に対する関心は强い にもかかわらず, 建造物の改築の問題, 経済的な理由, さらに歯科彰療のもつ特殊性のために，現状のままに放 䇫されているのが実状のようである。

(本研究の調查に御協才いただいた北儿州市柬科医即 会，ならびに関係医療㙨関に感謝しまず.)

献

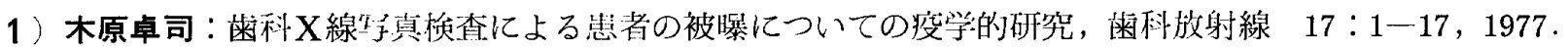

2 ）丸山隆司・橋詰 雅・他：柬科口内法撮影による国民線量の研究，柬科放射線 $17: 52-63 ， 1977$.

3) 丸山隆司・野田 豊・他：歯科X線撮影によるリスクの推定, 橉科放射線 $19: 1 \cdots 7,1979$.

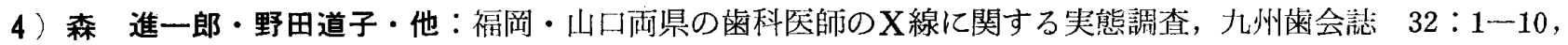
1978 .

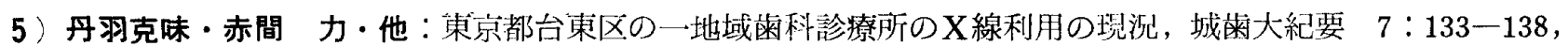


1978.

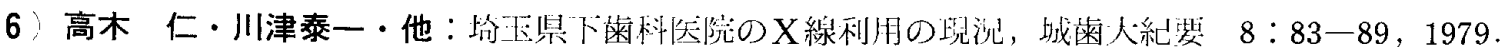

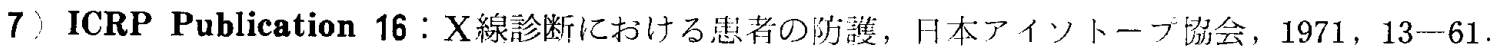

